\title{
Finding Direction at the Edge of Law and Life: Islamic Figh, Correspondence, and UAE Takäful Insurance Regulation
}

\author{
Iyad Mohammad Jadalhaq ${ }^{(D)}$ and Luigi Russi ${ }^{(D)}$
}

\begin{abstract}
The Islamic legal enterprise forms an inherently plural system that can appear puzzling to commentators looking for faithfulness to principle or precedent. When one looks at it, instead, as an ongoing search for correspondence between divine guidance, rooted in the foundational sources of Islam, and the singularity of concrete circumstances, Islamic law is revealed as a practice of discernment against the grain of the particular. This article unfolds this approach to understanding Islamic law by entering the conversation where it is currently most heated, namely in connection with the development of Islamic financial products. A case study of takâful regulation in the United Arab Emirates (UAE) helps substantiate the import of our proposal for attuning to the voice of Islamic jurisprudence (fiqh), in the face of contemporary questions arising from the design of financial products in correspondence with the Sharïah.
\end{abstract}

Keywords: Law and society, legal anthropology, takäful, fiqh, correspondence, United Arab Emirates

\section{Résumé}

L'entreprise juridique islamique forme un système intrinsèquement pluriel qui peut sembler déroutant pour ces commentateurs qui ne recherchent qu'une fidélité aux principes ou aux précédents. Lorsqu'on l'analyse, au contraire, comme une recherche permanente de correspondance entre la direction divine, enracinée dans les sources fondamentales de l'Islam, et la singularité des circonstances concrètes, le droit islamique se révèle comme une pratique de discernement à contre-courant du particulier. L'article examine cette façon d'aborder le droit islamique, en entrant dans la conversation là où elle est actuellement la plus animée, soit dans son lien avec le développement des produits financiers islamiques. Dans cette foulée, une étude de cas sur la réglementation takāful aux Émirats arabes unis (EAU) est proposée afin de justifier l'importance de notre proposition d'adapter la jurisprudence islamique (fiqh) face aux questions contemporaines posées par la conception de produits financiers en correspondance avec le Sharî̀ah.

Mots clés : Droit et société, anthropologie juridique, takāful, fiqh, correspondance, Émirats Arabes Unis 


\section{Introduction}

In this article, we approach Islamic law as practice and process, rather than as a logico-deductive system. This amounts, first, to a statement around how Islamic law manifests: namely as a phenomenon that takes place at the confluence of many strands of activity (source selection, textual hermeneutics, devotional practice, factfinding, social and commercial custom) that all occur simultaneously in the search for legal direction. This is what this paper refers to as the "Islamic legal enterprise," to underscore the process of self-specification of Islamic law, through the work of its skilled practitioners. Second, in order to attempt such a description of Islamic law, we adopt a socio-legal lens that foregrounds the situatedness of the practitioner, as he/she researches the legal response to a practical problem. The law, we argue, is what manifests in the process of finding an orientation in the face of an impasse: it does not already exist, in the form it takes through confrontation with the singularity of particular cases, before that confrontation-legal guidance appears as and when it meets practical occasions that call forth its self-specification. Therefore, the variety of life makes a difference to the law and, in fact, helps disclose it against the grain of the world's becoming. In socio-legal terms, this places our contribution in the domain of post-structuralist scholarship (Shatzki 2012, 13), which we understand as animated by a concern not to take the structural properties of legal systems as a starting point, and investigate instead their formative processes-which often dig their roots in the very practical and piecemeal pursuits of jurists (Murphy and McGee 2015).

To move one step closer to the thematic focus of this piece, a suitable starting point is the parallel sketched by legal realist scholar Haider Ala Hamoudi (2007a, 614) between halāl chicken hot dogs and Islamic financial innovation. Haläl chicken "hot dogs" are designed to look like conventional pork hot dogs as much as possible, and they differ from their conventional counterparts only on the grounds of formal compliance with the prohibition against the consumption of pork meat, to which Muslims are bound.

The parallel between chicken hot dogs and Islamic financial products is unflattering, yet it draws attention to the blind spots and contradictions that punctuate the process of drawing guidance from the sources of Islamic law, in order to translate divine instruction into practical arrangements for social commerce. As the law's guidance tests, and is tested by, the singularity of real-life circumstances, a two-way process of discernment is set in motion. This process does not so much work like a one-off syllogistic subsumption of minor premises (concrete circumstances) under major premises (the rules of Islamic law). Instead, it entails a back-and-forth question and response, in which proposed legal solutions function as "working hypotheses" (Dewey 1924) to allow a provisional entry point into the impasses of social commerce, with a view to discerning what continuations Islamic legal reasoning might suggest for the plotlines of real-life transactions. ${ }^{1}$

Hamoudi is right to ask, when faced with a nearly indistinguishable product to a conventional financial instrument-or hot dog: is that all there is to it? However, he

We take the image of legal reasoning as the search for an ending to the unresolved plotlines arising amidst people from Boyd White $(1985,691-2)$. 
is too quick to leave that place of irresolution by moving for a solution. This he does when he dismisses as unserviceable the distinctive forms of reasoning found within the Islamic legal tradition (Hamoudi 2007b, 2008). In their stead, he suggests that the task befalling the Islamic legal enterprise would be better served by a more direct appreciation of the function that Islamic legal instruments ought to fulfil in the economy (Hamoudi 2007a, 620). This move appears to us to be too swift because it tries merely to substitute one box for another, placing "realist" economic function where "formalist" principles of Islamic law had been, namely: inside the major premise of a syllogistic cascade. Yet we feel that the deeper critique Hamoudi is voicing has to do with mechanistic approaches to legal decision-making. To pursue that critique consistently, we suggest, requires resisting the temptation to engage the "substance" of legal rulings separately from the constraints of "form," by which those rulings are achieved. Doing otherwise leaves untouched the assumption that there might just exist "boxes" of pre-packaged premises that can be substituted for one another inside a syllogistic "decision machine": an image that falls short of a truthful description of how legal rulings are actually produced (Dewey 1924).

Therefore, the motivation for the present study stems from our simultaneous recognition of the place of irresolution described by Hamoudi and lingering dissatisfaction with his suggestion of a turn towards functional concerns, and away from the formal constraints of Islamic legal reasoning. As an alternative to that, we propose to re-centre the image of the Islamic legal enterprise away from faithfulness to principle or precedent. ${ }^{2}$ Instead, we suggest looking at Islamic legal hermeneutics as an ongoing relay, or "correspondence," between the unresolved lines of activity encountered in social commerce and the direction available within the corpus of Islamic jurisprudence. We understand this correspondence as the mutual specification of law and social practice. On the one hand, the Shar $\vec{i} a h$ manifests when its sources are summoned, again and again, to respond to ever-new questions issuing from social commerce. On the other, the development of social practices is oriented in its turn by the distinctions found in the sources of Islamic law. Our hope is that by retrieving something of the "style" by which the Islamic legal enterprise unfolds, the outlook for Islamic financial innovation might appear less either/or (either functional viability or formal loyalty to principle) than Hamoudi seems to leave room for. We submit instead that the correspondence of Islamic law with the singularity of life constitutes a more revealing description of the process by which legal guidance is achieved, through an always ongoing process of pursuing faithfulness to the Sharìah against the variable occasions of social commerce. On this reading,

2 "Faithfulness to precedent" is an expression we use to describe the approach of formalist currents in contemporary Islamic jurisprudence: their treatment of Islamic law is akin to a closed system of previous "rulings" (assembled and validated through various juristic modes of reasoning around the sources of Islamic law) that are regarded as formally binding, and applied "mechanically" (Hallaq 1985-86, 81-82). Instead, "faithfulness to principle" seems to us to capture the "functionalist" position-of which Hamoudi is a vocal proponent-whereby the Sharĭah primarily advances a set of normative goals or principles, with formal modes of reasoning being peripheral and contingent to their successful implementation in concrete circumstances (Hamoudi 2007a, 620-21). 
Islamic law provides an insightful case that socio-legal scholars would do well to consider in the search for clarity around how law and life intersect.

We develop our argument in three movements. In the first (Section II), we attempt to reconstruct the style by which legal assessments are achieved within the Islamic legal tradition. In particular, we consider the recent work of rhetorician W. E. Young (2017), which describes how the inquiry into whether an earlier ruling ( hukm) might "fit" a new case originates, historically, in the back-and-forth process of disputation between an actual proponent and respondent. Young's work is important, in our view, because it gestures towards a more encompassing formative movement, in the Islamic legal enterprise, based on a continuous back-and-forth relay to establish correspondence between the sources of divine guidance and the rich singularity of individual cases. This also entails the possibility that moments of paradox and irresolution will punctuate this iterative process of incremental clarification of (divine) law through life, and of life through law. In this light, the contemporary development of Islamic finance constitutes a paramount setting for witnessing the formative movement of Islamic law once again at work, inclusive of its moments of impasse.

Section III attempts to situate this perspective inside the actual development of Shar $\vec{\imath} a h$-informed financial products. In particular, it charts the evolution of takäful, which could be described to a Western audience as a form of mutual insurance in which risks are not transferred (to the insurer, who becomes liable for them), but rather pooled by a group (so that if the group funds run out, the risk reverts to the individual). Hamoudi (2008) is correct in pinning the historical origin of takäful insurance on the search for an "Islamic equivalent" of conventional insurance. However, form and function have not moved along the parallel tracks feared by Hamoudi. Instead, the recent development of the waqf model of takaful issues from a formal process of ensuring less "strained" compliance with Sharïah requirements, but it also succeeds in putting forth a persuasive proposal for how insurance provision might functionally operate within the Muslim polity. Finally, the section locates this evolution within the specific trajectory of takäful regulation in the jurisdiction of one the authors, namely the United Arab Emirates (UAE).

Section IV further elaborates on our attempt to open up the "black box" of Islamic legal hermeneutics. In particular, it elucidates the methodological import of the choice to move from "names" to "processes," tracing it back to the work of Gregory Bateson. A process view of Islamic law as a living tradition lends credit to "correspondence" as a viable metaphor for capturing something of the co-evolution of Islamic jurisprudence and lived social practices. The section also situates the notion of correspondence in the context of Rosen's (1989) suggested interpretation of the task of legal intervention in Muslim society. Lastly, the conclusion recapitulates the progression of this piece, tying up our main claims and suggestions.

\section{The "Jurodynamics" of Correspondence in Islamic Legal Development}

"Sharïah" means "path to the water hole" in archaic Arabic (Weiss 2006, 17). This is a metaphor to describe a way of life that (through conformity with divine will) 
ultimately leads to well-being: obedience to divine will does not present itself as a blind dictate, but as a passageway to meaningful spiritual and physical fulfilment (El Fadl 2014, xxxviii). The metaphor of the way, or path, also brings with it a sense of a continuously unfolding journey, which progresses in lockstep with one's effort of walking the trail. Khan has captured poignantly this sense of movement that lies at the heart of the Sharīah, as divine law, through the notion of "jurodynamics" $(2009,232)$.

Jurodynamics recognizes the Sharïah as an ongoing "opening out" of divine will in response to the evolving circumstances of life that make human beings turn to it for guidance. True, Muslims believe the Qur'ān to be God's directly revealed word to the Prophet Muhammad, peace be upon him (PBUH). They also view the narrative tradition of reports (hadith) on the life of the Prophet as the other foundational text of God's revealed law. The collections of hadith reporting the Prophet's deeds and oral teachings are collectively known as the Sunna. Through the sayings and deeds of the Prophet, they afford another basic entry point into a knowledge of morals in accord with divine will. Altogether, these two foundational sources (the Qur'än and the Sunna) do not constitute repositories of already formed assessments that ought to be directly applicable to all possible circumstances that may demand divine guidance. Rather, they are best seen as "a quarry in which the astute enquirer can hope to find the building blocks for a morally valid, and therefore true, system of ethics" (Reinhart 1983, 189). To be able to drink from the well of moral knowledge that the Shariah holds, one needs actively to walk its path, and that path involves an ongoing interpretive "effort" (ijtihād) that the qualified interpreter must face. This effort is needed to draw out the meaning of revealed law in order to arrive at helpful normative assessments for the believer to move forward, amidst the circumstances of social life, in conformity with divine will.

This explains why Islamic law, once properly understood as a process of drawing out normative guidance from foundational sources of divine revelation, acknowledges additional sources that are not themselves "texts," but rather modes or techniques for "discovering" the law (Rosen 1989, 42). The first of these is ijmā, which is a consensus amongst legal scholars about an interpretation of the foundational texts on a particular point, and the second is qiyās, or analogical reasoning (Bassiouni and Badr 2002, 152-57). ${ }^{3}$ Together, these sources (Qur'ān, Sunnah, $i j m \bar{a}$ and qiyās) are commonly understood to be the "roots" (usul) of fiqh, fiqh being the process of "drawing out" normative assessments from the foundational sources found in the Qur'än and the Sunna (Reinhart 1983, 188).

Since the ascertainment of divine will in concrete circumstances demands the intervention of a human interpreter, conformity with the Shari $\vec{a} h$ does not entail an obligation to guess the one "right" interpretation. Rather, it merely requires that the interpreter expend his/her maximum effort to attain a satisfactory legal assessment of the circumstances at hand (Weiss 2006, 121). The Shar $\vec{\imath} a h$, therefore,

While the Qur'än, Sunna, ijmā, and qiyās are sometimes reported as the "canonical" sources of Islamic law, Bassiouni and Badr $(2002,141)$ clarify that ijmā and qiyās are just two amongst a host of available methodologies for determining law's dictate in the face of individual circumstances. 
appears as an open-ended path that is populated through the recursive attempts at interpretation demanded of successive generations of interpreters. This organizational form, of an open-ended whole that is continuously constellated by a succession of parts, has equally been described as a broader feature of Arab literature (with collections of episodes loosely gathered inside an open-ended framing tale), architecture (with mosques formed from modular parts that compose a whole through their recursion), and mathematics (with infinite algebraic sequences) (Slater Gittes 1983).

In the history of Islamic law, this has meant a tolerance for the plurality of interpretive opinions, resulting in the sedimentation of different bodies of jurisprudence produced by the hermeneutical work of communities of "juristic theologians" (Menski 2006, 312) during the formative period of classical Islamic law, up until the ninth century CE. ${ }^{4}$ This eventually led to the establishment of four main schools of jurisprudence, or fiqh: namely the Shāfí̀ ${ }^{1}$, Hanbalī, Mālikī, and Hanafī schools (Alarefi 2009).

Central to discerning the normative assessment that ought to apply to a given set of circumstances is the work of going back and forth between the foundational texts of Islamic law and the specifics of concrete situations. ${ }^{5}$ This relay establishes a correspondence, that is, it sets in motion a process in which the sources of Shariah are interrogated for guidance by an interpreter, and circumstances are in turn probed for the "occasions" they lend to this, or that, normative evaluation. This entails viewing the formulation of the law as a "partnership" (Weiss 2006, 128) between the work of the interpreter and the plane of practice.

Recent work from rhetorician W. E. Young (2017) helps further substantiate this point. His work builds on earlier studies by Hallaq (1999), which show that legal opinions were not originally issued by an individual legal scholar acting on his own. Rather, they were arrived at through a process of intersubjective disputation in which, through question and response, the disputants would arrive at a shared sense of not being able to further challenge or refine a proposed interpretation, allowing it to stick. Young describes, in particular, the work of testing the proposed analogical extension ( $q i y \bar{a} s$ ) of a ruling, which applies to a "root" case, to a similar "branch" case. Jurists involved in this process of disputation would seek to arrive at a shared formulation of the "occasioning factor" ('illa), to warrant a similar legal outcome in both the root and the branch case.

4 A product of a later historical stage in the development of Islamic law, legal maxims (al-qawä'id al-fiqqiya) are distillations of rules and principles drawn from the body of fiqh. These maxims enter the process of correspondence between law and life as an aid for jurists (Elgariani 2012), by providing a panoramic view of the interpretive possibilities carried by the extant tradition. However, they do not erase the jurist's skilled work of grappling with the fine-grained particularity of each practical situation in order to specify the meaning of the Shariah in relation to concrete circumstances (Kamali 2006, 86).

5 We follow Weiss $(2006,134)$ in underplaying the supposed rift between the hermeneutical skills implicated in taqlìd and in ijtihäd. Taqlìd denotes a supposedly less innovative practice of issuing legal opinions based on reliance on the corpus of jurisprudential opinions already sedimented within each school of Islamic jurisprudence, as opposed to independent derivation of those opinions by a qualified jurist (mujtahid) working directly from the foundational texts-as it occurs in the practice of ijtihād. See also Hallaq (1984). 
Islamic jurists went as far as to qualify their degree of shared persuasion in the proposed analogy by distinguishing different "types" of qiyās. In some cases, the disputants might have merely agreed on one or more external circumstances that recurred in the two sets of cases, as an indication of a superficial similarity between them, without being able to formulate a common belonging in more revealing terms (qiyās al-dalala). At other times, a more incisive formulation would emerge through the disputation process, leading to what was called qiyās al-illa. These distinctions suggest that the 'illa be viewed not so much as an "essential," a priori, property of real-life cases that ought to be guessed; one might argue instead that "the 'illa used in legal arguments is conjectural" (Shehaby 1982, 36). In other words, the 'illa might be better understood as a "working hypothesis" or "conjecture" issuing from joint inquiry between a proponent and a respondent, in the form of a back-and-forth search for correspondence between a root and a branch case-against the question of whether the legal evaluation applying to the former ought also to extend to the latter. For our purposes, what Young's rich and complex empirical work shows is that the dynamic search for fittingness, or correspondence, between legal determinations and concrete circumstances forms a distinctive feature of jurisprudential activity in Islamic law. So much so that interpretation was originally embodied in an actual process of intersubjective question and response through which legal assessments could be scrutinized and accepted.

This style of "corresponsive" inquiry implies paying special attention to the singularity of each set of circumstances that interrogate the foundational texts for guidance. It also entails the possibility that different sets of circumstances might "activate" different possible correspondences between law and life, to the point of warranting a departure from previous judgments. As an illustration of this point, it is interesting to consider a Mālikī opinion reported by Al-Salami (1999, 24). This opinion admits that a certain 'illa might be found in common between root case A and branch case B. However, it also allows that a subsequent assessment of case B (as root) vis-à-vis case C (as branch), might lead to finding a new 'illa as the justification for analogy, even if analogy had been previously undertaken between $\mathrm{A}$ and $\mathrm{B}$ on the basis of a different occasioning factor. ${ }^{6}$ Here, the contrast afforded by a new set of circumstances sparks legal inferences that can diverge from previous assessments. This opinion is also revealing because it affords a foothold for accepting relative freedom from tradition, which constitutes an enduring possibility in Islamic law, as an integral part of fiqh hermeneutics. This is additionally exemplified by doctrines that allow a jurist to set aside earlier opinion in the face of the particularities of new situations, such as istisläh (choosing a less directly related precedent over a more directly related one, in order to achieve equity) or istihsān (breaking with precedent in the pursuit of a just result, in the light of the concrete circumstances of the case) (El Fadl 2014, xxxvii).

6 Contra, see Shehaby $(1982,28)$, who mentions that not all jurists would find it acceptable to use cases already decided through analogy as the basis for a new chain of analogical reasoning. 
The recursive search for "fittingness" between the direction provided by the law and the concrete circumstances that demand clarification affords centrality to the role of persuasiveness (Tomeh 2010, 168). Persuasion is reached when a "best fitting" assessment is found for the case at hand. This is when the attendant atmosphere of intense scrutiny subsides, and a sense of clarity takes its place-a shift that some commentators report as a reliable indicator that the inquiry has reached its natural pause (Al-Salami 1999, 104; Tomeh 2010, 160).

The foregoing considerations help substantiate our proposal to regard Islamic law as a process of discernment of moral knowledge that gives prominence to concreteness and particularity over systemic coherence. In the light of this, variation in legal assessments is to be properly understood less as a mark of failure, and more as a flexibility distinctive of the Islamic legal enterprise, which emanates from the (always ongoing) search for a "best fit" between divinely ordained law and life. These considerations afford greater insight into the "jurodynamic" process, which allows Islamic legal reasoning to work incrementally towards legal architectures that conform to the Sharīah in increasingly persuasive ways (Abdullah 2013, 38). The next section attempts to illustrate this "style" of legal hermeneutics at work in connection with the formulation of a Sharìa-compliant insurance product known as takäful.

\section{Takäful Regulation as Search for Sharïah Conformity, with a Case Study on the UAE}

Hamoudi $(2008,463)$ is correct in positing that the development of an Islamic jurisprudence on financial matters is a recently new acquisition, and one that was historically stimulated by the impetus to differentiate a Muslim polity against the backdrop of a global political and economic sphere.

As a consequence of those historical pressures, fiqh has been mobilized to work out an "Islamic approach" to financial and commercial practice. However, where our assessment of the situation differs from Hamoudi's is that the consultation of Islamic law to investigate what forms financial transactions might take-so that they align with the Shariah-is not driven solely by those historical pressures towards differentiation of a Muslim polity. Instead, we submit that Islamic jurisprudence has something genuinely original to say, in its own voice. In this respect, we would like to suggest that the import of a corresponsive style of legal reasoning is that the law gets continuously called into question by social practice. Conversely, though, the effort expended by the legal interpreter is in turn capable of returning insightful responses to the field of practice, to the point of expanding the imagination of available possibilities for the organization of a common life. For example, in connection with takäful insurance, an in-depth engagement with what might initially appear as legal technicalities eventually ushers in new possibilities for a transformed understanding of the place "insurance" might occupy in the Muslim polity. As the following sections show, the shift is one from implementing takâful insurance as a Western-style individual bailout agreement-which is what the tabarru' model effectively achieves-to insurance as something akin to a community service through the waqf model (Çizakça 1998). 


\section{The Tabarru' Model of Takāful}

Takâful is the example Hamoudi (2007a, 2008) chooses to substantiate his mistrust of fiqh as a tool for developing workable Islamic financial practices. Instead, we want to suggest that the jurisprudential debate around takâful could be equally construed as an illustration of the corresponsive style that is distinctive of Islamic legal reasoning. On our reading, regulatory blind spots and contradictions are not the endpoint. Rather, we argue that it is precisely those blind spots and contradictions that have offered reasons to recalibrate jurisprudential inquiry into the sources of Islamic law, in order to derive more apposite guidance for aligning insurance provision with the Sharỉah.

Conventional insurance involves the transfer of risk from the insured to the insurer, in exchange for the payment of a premium. This scheme was declared incompatible with the Shar $\vec{\imath} a h$ in a series of fora of Islamic legal scholars, starting in 1965.

Typically, those legal opinions (fatāwā) have underscored what Islamic insurance ought not to be like (El Gamal 2007, 187). However, the statement of what is prohibited (harām) is usually just a first step in the search for permissible arrangements-a search that might occasionally involve skirting close to acceptable limits in order to test which forms might best fit the goal of fidelity to the Shari ah. Rosen $(1989,56)$ has observed that a central feature by which Islamic legal reasoning retains sufficient responsiveness to adapt to concrete circumstances is precisely through such statements of broad (negative) limits to human initiative, without specifying in detail what (positive) courses of action ought to be chosen in the realm of the permissible. This leaves open the possibility to work out any positive implications in close correspondence with findings from practice.

From an Islamic point of view, Western commercial insurance appears to breach the prohibition against "excessive risk" (gharar), because it creates a commutative contract, in which one or both parties do not know what they will obtain as a result of the deal (for the insured: compensation, or loss of the premium instalments; for the insurer: only the premium instalments, or instalments minus compensation payouts) (Bekkin 2007a, 22). Some scholars have gone as far as to say that insurance contracts amount to a gamble (maysir), like a "wager" by the insurer that the insured will not incur the insured events. However, an argument against this interpretation is that-unlike a gamble-the underlying intention is very different, namely to minimize risks as opposed to amplifying them (Bekkin 2007a, 26). In other words, an insured who gets paid does not "win" anything, but is merely receiving compensation for a loss. Finally, because insurance involves the exchange of money for money with an element of time delay, this falls foul of the prohibition of like-for-like, deferred trades-itself a corollary of the prohibition on interest $(r i b \bar{a}) .{ }^{8}$ However, since the main purpose of an insurance transaction is to

For a detailed timeline of the evolution of the prohibition against conventional commercial insurance, see Bhatty and Nisar (2016).

8 On the debate surrounding the proper content and purpose of the riba prohibitions, see the seminal work by Fadel (2008). 
insure someone against losses, rather than exchange money for money in deferred fashion, this argument carries less weight (Bekkin 2007a, 29). In view of this, it is the presence of gharar (substantial elements of uncertainty in a commutative contract) that forms the centrepiece of the Islamic prohibition on conventional commercial insurance (Abozaid 2016, 96).

As a consequence, an initial direction of jurisprudential exploration in the face of this prohibition has focused on re-packaging insurance in a different form from the commutative contract. At this early stage, "skirting close" to acceptable limits might be construed as a heuristic strategy to test out the lawfulness and practicability of possible solutions (Weiss 2006, 170). This is how takafful was born, in the (controversial) form that is currently most in use: the tabarru' model. In essence, a typical takäful scheme is usually operated by a company limited by shares, which manages a takäful fund on behalf of participants in the scheme. The takäful fund works like a pot into which participants contribute, and from which they will receive a payout in case a specified negative event befalls them. The "pot" is held within the company that operates the takäful fund and managed separately from its other assets: from a formal point of view, the company is being contracted purely to manage the participants' takäful fund, and not to take upon itself the participants' risks (as in a conventional insurance scheme). ${ }^{9}$ Participants contribute to the takäful fund through a donation (tabarru') and receive, in turn, a counter-donation from the fund in case a specified negative event befalls them. The company that manages the takäful fund does so under a separate contract, either through an agency (wakalah) agreement or as the provider of labour in a partnership (mudarabah) (AlNemer 2013). This scheme formally bypasses the gharar prohibition by breaking up the conventional insurance agreement into two separate donations. Doing so, however, creates a few problems. For instance, how can takäful participants perform a donation in view of a payout? Furthermore, considering they have joined the takäful scheme on a donation basis, is their "right" to compensation even enforceable? In the face of these questions, it has been argued that if a participant's donation is conditional, then it isn't really a donation, and so the participant has effectively entered a commutative contract with the takafful provider, incurring the very same prohibition of gharar that the donation sought to circumvent (Agha 2010, 84; Abozaid 2016, 97). ${ }^{10}$

Despite these objections, the takäful scheme has become widespread in the Muslim world. In this piece, we specifically illustrate the reception of this model in

9 If the takäful fund is insufficient to cover the amount of payouts, the takäful provider might step in with a gratuitous loan (qard) to be recouped against future contributions to the fund. Since this is close to a transfer of risk upon the takäful operator (Agha 2010, 82), qard loans have been explicitly restricted, e.g., in the Sudanese model of takäful (Al-Darir 2004).

10 Technically speaking, takāful is "a mutual pact made by a group of individuals to fulfil the needs of each other" (Nana 2016, 63) in the event of a negative event. An alternative construction could have been a joint guarantee contract (tadāmun), where a group of people agreed to act as mutual guarantors, establishing joint and several liability between themselves, in relation to the scope of the guarantee (see, e.g., art 450 of the UAE Civil Code). To make tadāmun work like a premium-based insurance scheme, however, would have also run against the altruistic orientation of the guarantee in classical Islamic jurisprudence (Ab Rahman 2008, 344-45), which makes it problematic to agree for any payments to be arranged in return for acting as guarantor of another (Al-Dusuqui 2011,77). 
the jurisdiction of one of the authors, a private law professor from the UAE. Our findings on this point do not issue from the application of a social scientific methodology, supplementary and external to the routine work of "doctrinal" research. This is consistent with the orientation pursued throughout the paper: to simply follow habitual methods deployed by practitioners in the search for legal guidance in order to glimpse the dynamic process by which they gradually specify a system of law-through the negotiation of piecemeal encounters with ambiguous and puzzling circumstances. In a contemporary Muslim jurisdiction, "doctrinal" research involves scrutinizing national bodies of law (qanun), in the face of the largely transnational conversation on the Shari $\vec{a}$ h assessment of different regulatory issues (Khan 2009, 284-85). In the case of the UAE, this relationship between positive law and the Shar $\vec{a} a h$ is explicitly acknowledged by Art. 1 of the Civil Code (Jadalhaq and El Maknouzi 2019

Returning to takäful insurance, careful scrutiny of the conversation on Islamic fiqh suggests a discrepancy between (i) current state-enacted instruments on Islamic insurance in the UAE, which privilege the tabarru' model of takäful, and (ii) orientations that seem more defensible in the light of the Shariah. Doctrinally, our piece calls attention to this discrepancy. From a socio-legal standpoint, it doubles as an illustration of the practice of negotiating misalignment between "formants" (Sacco 1991) in the contemporary landscape of Islamic jurisprudence.

In the UAE, takäful insurance has been regulated through positive law (qanun), and falls within the regulatory remit of the Insurance Authority, which was brought into being by Federal Law No. 6 of 2007 on the Establishment of the Insurance Authority and Organisation of its Operations (UAE Insurance Law). Beyond establishing the public insurance regulator, the UAE Insurance Law also makes an important determination concerning the legal subjects that may operate a takäful fund, namely public stock companies (Article 24). This enshrines a limitation, whereby takāful may not currently be operated in mutual form (Carmody 2016). ${ }^{11}$

Another central instrument defining the legal regime for Islamic insurance in the UAE is Resolution No. 4 of 2010 of the Insurance Authority, Concerning the Takaful Insurance Regulations (UAE Takaful Insurance Regulations). The UAE Takaful Insurance Regulations make it clear, at Article 1, that contributions to the takāful fund are to be provided by participants through a "commitment to donate" which comes from the Mālikī school of jurisprudence (Iltizaam bit Tabarru'). According to this scheme, participants make a unilateral promise binding themselves to undertake voluntary contributions towards the fund. Used in the context of takäful insurance, however, this arrangement has been charged of effectively amounting to a commutative contract (Nana 2016, 72).

11 The mutual form is another suitable fit for Islamic insurance, although its theoretical suitability clashes with the practical difficulty of setting up a mutual company in a context of geographical dispersion of potential takäful participants (Bhatty and Nisar 2016, 15). This means that even where the mutual form has been imposed through regulation, as in Saudi Arabia, applicable legal requirements have brought it substantially closer to a joint stock company (Alghamdi 2013). 


\section{A New Generation of Takäful Schemes: The Waqf Model}

While Hamoudi (2007a) takes the tabarru' model of takäful as a final demonstration of the formalism inherent in Islamic jurisprudence, we would suggest, instead, approaching jurisprudential elaboration around tabarru'-based takäful more sympathetically, as the initial step in a still-ongoing process of discernment of the proper place of insurance schemes amidst a Muslim polity.

The idea of takaful was developed by turning to the foundational texts of Islamic law, in the face of the aforementioned fatāwa against conventional commercial insurance. While the Qur'ān does not directly contemplate commercial insurance as known today, it does mention other communal arrangements like diyāh and zakät. Hence, Bekkin (2007a, 6) suggests that scrutinizing insurance provision against these arrangements establishes an analogy, which then helps clarify what further specifications and modifications would be needed-in a takäful scheme-to make possible a firmer assessment of permissibility in the light of the Sharìah. While the prohibition of gharar rules out a commutative contract for protecting against risk, diyāh and zakät are specific examples of communal provision. Diyāh refers to the blood money that paternal relatives ('aqilah) of a murderer were asked to pay to the heirs of the murdered member of another tribe. When the relatives of the murderer did not possess enough funds, this would entitle the relatives of the murdered person to retaliate. To prevent the cycle of retaliations, tribes would pool a special fund to discharge blood money obligations. In the light of its role in abating violence, diyāh was explicitly confirmed in the Qur'ān (4:92). Zakät is, instead, a communal tax that forms part of the basic duties of Muslims, which they are to discharge to support a fund providing for members of the community in conditions of special need ( $Q u r^{\prime} a \bar{n}$ 9:60). Together, these institutions offer an important indication, namely that certain risks can only be addressed in conformity with the Sharìah by mobilizing communal arrangements towards solidarity provision, placing protection from risk outside of the domain of bilateral agreements, whereby individuals might bail themselves out of risks to which they are exposed. "Pooling" entails something fundamentally different from "purchasing (for oneself)": it belongs in the sphere of communal duty, as opposed to that of individual prerogative. While diyāh and zakāt are not direct precursors of modern commercial insurance, they embody a distinctive approach to caring for people in need, namely through the establishment of community institutions rather than through individual arrangements. This appears to be the same line of reasoning followed by those who predicate the legitimacy of takâful on a hadith, cited by Bukhari and Muslim, relating the Prophet's (PBUH) praise of the tribesmen of al-Ash'ari for bringing their belongings in one pot when hardship struck them, in such a way that those assets, after being placed in common, might be distributed equally amongst them (Bekkin 2007b, 110). If this line of reasoning is correct, then one might conclude that the creation of communal structures for solidarity provision constitutes the positive side of the prohibition against commutative insurance contracts on grounds of gharar.

In this respect, the tabarru' model of takäful can at least be appreciated as an imperfect attempt at reaching this goal, because it takes a first step towards 
exploring the communal pooling of resources through a takäful fund. Still, because the fund does not have independent legal personality, it is typically deemed to remain the property of individual participants, in proportion to their contribution (Nana 2016, 73). This is the case in the UAE, as suggested by Article 24/4 of the UAE Takaful Insurance Regulations, which clarifies that assets on the "participants' account" ought to be kept separately from the takäful provider's own assets. In view of this, the enduring ambiguities in such an arrangement qualify the tabarru' model more as an initial exploratory step towards communal provision against risk. The clear establishment of a "third" actor, operating autonomously of bilateral arrangements between individual participants and the takäful provider, is hampered by countervailing elements such as the "commitment to donate" (which makes a donation work as little more than a stratagem to avoid a commutative contract) and retained ownership of takäful contributions by participants, despite their having parted from their contributions through a tabarru' donation towards the fund (Nana 2016).

A more refined step towards the achievement of communal solidarity provision in insurance seems to be possible by revisiting a historical organizational form long known to the Muslim world, namely the waqf (plural awqäf). The waqf is a perpetual endowment, set up for a charitable purpose, the revenue of which ought to be directed to the satisfaction of its charitable aims (Çizakça 1998). While originally undertaken as real estate endowments (like mosque buildings), awqā $f$ have become acceptable also as endowments of sums of money, in which the revenues from investing the principal can be directed towards the satisfaction of the founding purposes of the waqf. Çizakça $(1998,56)$ reports that cash awqäf were accepted in all the different schools of Islamic jurisprudence. Additionally, it is permissible for persons donating to a waqf to be eligible to receive from it, so long as they are mentioned as beneficiaries in the waqf deed. Last, but not least, the waqf has legal personality, so it acquires any funds donated to it, which it has to administer according to the stipulations by which it was set up (Nana 2016, 81). ${ }^{12}$ Taken together, these features of the wagf make it possible for it to be used as a suitable organizational arrangement for Islamic insurance, because it establishes a "third" entity-separate from the manager of pooled assets, and from individual participants-which presides over a communal provisioning scheme. From the above, this follows:

The payouts issued to the participants are not in exchange for their voluntary contributions ... they are based on an independent transaction which is not directly linked to the contribution made by the participant. The reason why it is considered an independent payout from the Waqf fund is that the participant is included among the beneficiaries of the Waqf according to the predetermined conditions of the Waqf. (Fidrus 2012)

12 Nana $(2016,83-84)$ suggests that management of the waqf funds be contracted out to the takäful operator on the basis of an agency (wakalah) agreement. The alternative of a mudarabah agreement would give the operator a stake in the subscription surplus (i.e. the portion of subscriptions that are leftover, after members' claims have been fulfilled). This would place the takäful operator in a position too close to that of a conventional insurer, sharing in the risks insured by participants. 
In this sense, the waqf can also be regarded as an improved take on the question of the function of insurance provision in a Muslim polity, by giving fuller actualization to some of the insights that first emerged in connection with the development of the tabarru' model of takäful. Indeed, the waqf model seems to align more closely with the social vision of building a commonwealth out of which to provide for the needs of community members than that of relying on "bailouts" on an individual basis (Alhumoudi 2012, 111-112). Adaptation of the waqf for the purpose of insurance provision accompanies a growing interest in this institutional form, which has been described by economic historian Çizakça (1998) as the centrepiece of a non-market system of social provision that brought a momentous historical contribution to the wealth of the Muslim polity.

This interest is also reflected, for example, in the promulgation in the UAE of the Federal Waqf Law No. 5 of 2018 (UAE Waqf Law). This law introduces a uniform discipline for the waqf endowment, differentiating in Article 4 between (a) "atomistic" endowments for the benefit of the original owner of the endowed assets, his/her children, or other specified persons; (b) charitable endowments set up to pursue an altruistic purpose; and (c) "joint" endowments that contemplate both "atomistic" beneficiaries and charitable goals. Moreover, at Article 31, the law acknowledges that awqäf established and managed in accordance with the UAE Waqf Law "shall enjoy independent legal personality." Still, the waqf does not appear to be compatible with the setup enshrined in the existing UAE Takaful Insurance Regulations: these contain mandatory arrangements for Iltizaam bit Tabarru' (commitments to donate) and for the separation of the participants' account from the takâful operator's own assets, which only make sense in connection with the tabarru' model. However, it is not to be ruled out-in light of these emerging orientations in Islamic jurisprudence on the suitability of the waqf to operate a takäful scheme-that the Insurance Authority might revise the UAE Takaful Insurance Regulations to contemplate the possibility of organizing communal insurance schemes using the waqf form. In that case, it is likely that the charitable waqf would be the most suitable candidate for housing operations for providing against risk, as a form of mutual assistance.

\section{Correspondence as Dialogue of a Living Tradition with Social Commerce}

This final section undertakes a richer reflection on the methodological approach we adopted for coming to grips with the process of jurisprudential elaboration $(f i q h)$ in connection with Islamic finance in general, and with Islamic insurance in particular. Our guiding intuition has been this: that the presentation of the interpretive work of Islamic jurists - as gleaned from Hamoudi's papers-risked driving one further away from an understanding of how Islamic jurisprudence might continue to function today, as it strives to respond to the new circumstances brought up by contemporary social commerce. Indeed, the cited papers by Hamoudi (2007a, 2008) seemed to us to approach Islamic jurisprudence merely as a "black box" (Callon, Lascoumes, and Barth 2009), an already-formed structure that merely 
strives to superimpose itself onto reality and, in the process, only yields ill-fitting outcomes-so that it ought to be cast aside.

Instead, our preferred approach has been to engage Islamic jurisprudence as though it were an ongoing learning process, a continual way of "finding" again (Coopchik 2015, 3) the import of divine counsel, in the face of the evolving circumstances of life. This position is mindful of the risk-besetting contemporary Islamic legal scholarship_of losing the ability to appreciate the distinctive "style" of development of the Islamic legal enterprise (El Fadl 2014, lv). This is why we sought to distance ourselves from the "black boxing" approach, which seems to us to discourage an understanding of Islamic legal development on its own terms. In response to that concern, we have chosen instead to follow the prompt of anthropologist Gregory Bateson (1979, 60-61): to move from "names" (i.e. treating "Islamic jurisprudence" as a body of knowledge and practice that is formed once and for all, and no longer subject to change) to "processes" (Conserva 1996, 42). In this, we were aided by the work of Reinhart (1983), who helped us retrieve the meaning of fiqh as "a verbal noun meaning understanding or discerning" (187, italics added). If "Islamic law" is treated as the nominalization of a verblike activity, then fundamentally "Islamic law is really a process of discerning what religious conduct is, what the sources of such knowledge are, and what the consequent statutes must be" (188, italics added). In addition, once fiqh is seen as a learning process leading to the progressive specification of divine guidance from revealed sources (in the face of concrete circumstances that need addressing), then another metaphor that lends itself to appreciate further the dynamism of Islamic law is that of "living tradition." This is a word used by philosopher MacIntyre to describe "an historically extended, socially embodied argument, an argument precisely in part about the goods which constitute that tradition" (2007, 222). The way we interpret this quote is as the description of an open-ended conversation, the focus of which is to clarify what exactly the subject of the conversation has been so far, so that the conversation might be carried into the future. If one tries to apply this description to Islamic law, this helps view the fiqh process as a relay between historically revealed sources and the upcoming puzzles of everyday social commerce-with the goal of discerning more clearly what it is that the Shariah might mean, in each new practical context in which it is called upon for guidance today.

To go back to Bateson, one implication of looking at Islamic law as process is that a process does not unfold "unilaterally," against an inert background. Rather, processes "co-evolve" with the life that keeps taking place around them. This is how we have come to yet another useful metaphor, that of "correspondence." This helps us describe the ongoing co-evolution of Islamic law in tandem with the ways of social commerce. Correspondence is a term that has been brought into wider use by anthropologist Tim Ingold $(2017,2015)$. By "correspondence," Ingold means "the process by which beings or things literally answer to one another over time" (2017, 15). This term carries with it an attendant focus on verbs (unfinished lines of activity) over subjects (fully formed entities), and a blurring of the distinction between "acting" and "being acted upon," in favour of being "carried along" streams of joint activity. 
In the context of our case study of takäful, the lens of "correspondence" helps reveal that it isn't only Islamic jurisprudence that is transformed/clarified in the encounter with the commercial practice of insurance-by undergoing a transition from the tabarru' model to the waqf model. Instead, the insights emerging from contemporary Islamic jurisprudence also question assumptions underpinning the conventional insurance business. For instance, one may draw from the waqf model broader questions about the conduct and purpose of insurance, such as: what does the waqf model show in terms of the implications of undertaking insurance as a private relationship between two persons (whereby one transfers their risks to another)? What alternative possibilities might be opened up by imagining insurance - in earnest - as a charitable endeavour of community provision against risk, inching closer to a mutualistic model? While these questions lie beyond the scope of this paper, they nonetheless illustrate the point that it is not just a matter of life calling into question the law (as when Islamic jurisprudence gets taken by surprise by the intractable "stickiness" of bilateral insurance contracts), but also of law calling into question the customary ways of social practice (what do different possible forms of insurance provision tell us about the insurance relationship, as currently practiced?).

In this sense, therefore, law and life appear as evolutionary lines that mutually correspond. And correspondence entails recurring, unresolved proximities in which new possibilities keep emerging to direct further investigation and ongoing transformation of law, as well as life. This can help tease out another feature of the style of Islamic jurisprudence, when it is regarded as process. In particular, correspondence gestures towards a form of recursive, back-and-forth communication that's more complex than a one-time "conversion" of law into life, or life into law: it transcends the alternative (i) of law simply having to conform to the ways of social commerce, or (ii) of social custom blindly having to comply with abstract legal principle. In connection with Islamic jurisprudence, the sense of an always-unresolved tension fuelling ongoing correspondence is captured by the shared etymology of "ijtiha $\bar{d}$ " (effort to interpret revelation) and "jihäd" (struggle for a divine cause): both derive from the root $j-h-d$, which refers to "striving" (Kamali 2002). It seems that every instance of legal interpretation involves not only an effort to ascertain and interpret the sources of divine guidance, but also a "struggle" with the seemingly intractable ambiguities and particularities inherent in real life situations (Lang 1996, 19) - a struggle that might even test the jurist's ability to respond in genuinely persuasive, and not merely formalistic, ways. When the ongoing development of Islamic jurisprudence is construed as a form of correspondence of law with life, this does not therefore rule out instances of collapse of law into the "realism" of life, or of life into the "formalism" of law. However, in the logic of correspondence, these moments are transformed, from endpoints that warrant no further continuation into stations of an ongoing process of struggle/interpretation that strives for the mutual clarification of law and life, i.e. (i) for the specification of the import of the Shari ah against concrete problems, and (ii) for insightful normative responses to the impasses and hesitations arising in social commerce.

Rosen (1989, 15-17) observes that appeal to the (revealed) sources of legal guidance occurs, in the Muslim world, in the context of an understanding of life as 
an unfolding trajectory; one that is brought into being by discrete encounters, in which a person is expected to negotiate autonomously his or her relationship of proximity or distance to others. When the possibility for such a negotiation is obfuscated, legal guidance is then meant to afford a new footing for interpersonal negotiation. This means that the role of Islamic law is to engage the particulars of each situation, without, however, going so far as to determine the course to be taken, which would do away with the possibility of individual negotiation of one's social position. Such observation brings forth a distinctive manner of proceeding in Islamic jurisprudential elaboration, which works by setting outer boundaries, whilst leaving room for the exploration of multiple (positive) courses of action (Weiss 2006, 170). When this approach is placed in the context of a process of recursive correspondence between legal interpretation and social and commercial practice, it is easier to grasp how it might lead to an incremental clarification of the scope of any negative limits and therefore prepare a more secure ground on which positive undertakings might be attempted.

To bring this back to our case study in Section III, we believe that our discussion in that case shows that the back-and-forth relay between, on the one hand, revealed sources and jurisprudential opinions and, on the other, the concrete details of takäful insurance provision has led to a progressive refinement in the understanding of what it is that is prohibited: from excessive risk in commutative contracts, to the transfer of risk in commutative contracts, to the provision of insurance through bilateral relationships that work as individual "bailouts." Symmetrically, this has allowed progressively more focused (positive) arrangements: from formalistic splitting of a bilateral insurance contract into separate tabarru' donations, to a focus on the takafful fund and its need for greater autonomy from bilateral arrangements, to placing the fund in an independent legal person like a waqf, to the charitable purposes that justify establishment of a cash waqf.

In view of this, we conclude that approaching Islamic law as a process of continuous correspondence with the particular circumstances of real life problems ultimately lends credit to the hypothesis of the enduring "aliveness" of the Islamic legal enterprise, still active today in the incremental clarification of the meaning of divine guidance (Sharïah). This enduring hermeneutic activity, we suggest, is not to be seen as extraneous to the "proper" functioning of Islamic jurisprudence, taken as an unchanging "black box" that ought to be blindly imposed on the reality of life. Instead, it constitutes the very fulfilment of the aspiration to make the Shariah explicit, in ways appropriate to the needs of temporally and geographically heterogeneous communities of believers (Al-Salami 1999).

\section{Conclusion}

This article has attempted to revitalize an appreciation of the enduring vitality of the Islamic legal enterprise to navigate some of the complex questions thrown up, for example, by the development of Islamic finance. In this piece, we have attempted to describe the Islamic legal enterprise as a process of establishing correspondence between law and life, through the juxtaposition of newly encountered situations with already normed instances. This contrastive proximity, we 
suggest, demarcates a field of inquiry in which new possibilities might emerge to specify further the import of divine precepts in the face of contemporary social practices. On this reading, the work of Islamic jurisprudence (figh) constitutes an activity of ongoing discernment that retains the ability to speak with an original voice even today, by unsettling and challenging accepted practice in social commerce through the insights generated by re-entering the revealed sources of the Sharīah.

In this article, we investigated how this process might be at work in practice by charting the contemporary evolution of jurisprudential elaboration in connection with Islamic insurance (takäful). Starting with an initial phase focused more on formal compliance with the prohibitions found in Islamic law (i.e. against excessive risk, or gharar, in commutative contracts), it seems to us that significant learning has occurred in the face of the issues left unresolved in that phase. In particular, contemporary jurisprudential elaboration on takâful insurance appears on course to mature from an initial exploration of acceptable limits (which at times might give the impression of purely formal compliance) towards more persuasive organizational forms - such as the waqf - that reveal something further about the meaning of the prohibition of conventional insurance on grounds of gharar. In particular, renewed scrutiny of takäful alongside such institutions as diyāh and zakät lends credit to the suggestion that risk provision be undertaken, in a Muslim polity, through communal organizational arrangements that are clearly distinct from the logic of individuals being able to "bail themselves out" of certain risks connected with life. Commutative insurance contracts fall into the latter case, in contrast with the establishment of waqf endowments with legal personality, which provide compensation for losses according to their statutory goals of protecting against risks. In this sense, while the UAE legislation on takâful currently abides by the model of a "bilateral" donation (tabarru'), recent legislative encouragement of the waqf through an apposite law seems to foreshadow the possibility of it becoming accepted as a legitimate vehicle for implementing takâful risk sharing.

Finally, we argued that the metaphor of correspondence between law and life is a methodological choice that makes it possible to retrieve what is enduringly alive in the Islamic legal enterprise, by allowing us to approach fiqh as an ongoing process, rather than as a fully accomplished logico-deductive system. This metaphor makes it possible to appreciate further the always ongoing clarification of the meaning of divine guidance, warranting the claim that the Shar $\vec{\imath}$ ah's validity holds in the face of the heterogeneous situations that a temporally and geographically diverse Muslim polity must face. It constitutes a rich deposit of possibilities for those who diligently inquire into it, in the search for equitable ways forward in accordance with the rules of religion.

\section{References}

Abdullah, Mace. 2013. Fraud and Deceit: Comparative Law Issues. International Centre for Education in Islamic Finance. https://www.academia.edu/3639684/Islamic_Law_ of_Contracts_Fraud_and_Deceit. 
Abozaid, Abdulazeem. 2016. Critical shari'ah review of takaful structures: toward a better model. In Takaful and Islamic Cooperative Insurance: Challenges and Opportunities, ed. S. Nazim Ali and Shariq Nizar, 93-111. Cheltenham: Edward Elgar.

Ab Rahman, Suhaimi. 2008. The influence of classical interpretation on the Law of Guarantees in the United Arab Emirates. Arab Law Quarterly 22:335-58.

Agha, Oliver. 2010. Tabarru in Takaful: Helpful innovation or unnecessary complication? UCLA Journal of Islamic and Near Eastern Law 9:69-86.

Alarefi, Abdullah Saad. 2009. Overview of Islamic law. International Criminal Law Review 9 (4): 707-31.

Al-Darir, Siddiq. 2004. Shari'ah Principles for Conducting the Insurance Business. Khartoum, Sudan: n.p.

Al-Dusuqui, Ibn Arafah. 2011. Al-Dusuqui's Commentary on al-Sharh al-Kabir (volume 3). Beirut: al-Ilmiyah.

Alghamdi, Sarah. 2013. The Saudi T'awunì insurance model: Concerns about Compatibility with Islamic law in accommodating 'risk'. Master's Thesis, University of Toronto. https://tspace.library.utoronto.ca/bitstream/1807/35106/5/Alghamdi_Sarah_S_201303_ Masters_Thesis.pdf.

Alhumoudi, Yuosef A. 2012. Islamic insurance Takaful and its applications in Saudi Arabia. $\mathrm{PhD}$ Thesis, Brunel University. http://bura.brunel.ac.uk/handle/2438/744.

AlNemer, Hashem Abdullah. 2013. Revisiting Takaful insurance: A survey on functions and dominant models. Afro-Eurasian Studies 2 (1/2): 231-53.

Al-Salami, Muhammad Al-Mukhtar. 1999. Al-Qiyas (analogy) and its modern applications. Jedda: Islamic Research and Training Institute.

Bassiouni, M. Cherif, and Gamal M. Badr. 2002 The Shari'ah: Sources, interpretation, and rule-making. UCLA Journal of Islamic and Near Eastern Law 1:135-81.

Bateson, Gregory. (1979) Mind and nature: A necessary unity. New York, NY: E. P. Dutton. Bekkin, Renat I. 2007a. Islamic insurance: National features and legal regulation. Arab Law Quarterly 21 (1): 3-34.

- 2007b. Islamic insurance: National features and legal regulation. Arab Law Quarterly 21 (2): 109-34.

Bhatty, Ajmal, and Shariq Nisar. 2016. Takaful journey: the past, present and future. In Takaful and Islamic Cooperative Insurance: Challenges and Opportunities, ed. S. Nazim Ali and Shariq Nisar, 1-21. Cheltenham: Edward Elgar.

Boyd Whyte, James. 1985. Law as rhetoric, rhetoric as law: The arts of cultural and communal life. The University of Chicago Law Review 52 (3): 684-702.

Callon, Michel, Pierre Lascoumes, and Yannick Barth. 2009. Acting in an uncertain world. Cambridge, MA: MIT Press.

Carmody, Sara E. B. 2016. New horizons: the potential for shari'ah-compliant cooperative and mutual services. In Takaful and Islamic cooperative insurance: Challenges and opportunities, ed. S. Nazim Ali and Shariq Nisar, 115-31. Cheltenham: Edward Elgar.

Çizakça, Murat. 1998. Awqaf in history and its implications for modern Islamic economies. Islamic Economic Studies 6 (1): 43-70.

Coopchik, Spencer J. 2015 Judicial decision-making in islamic banking and finance. European Journal of Islamic Finance 2:1-15.

Conserva, Rosalba. 1996. La stupidità non è necessaria: Gregory Bateson, la natura e l'educazione (Stupidity isn't necessary: Gregory Bateson, nature, and education). Florence: La Nuova Italia.

Dewey, John. 1924. Logical method and law. Cornell Law Review 10:17-27.

El Fadl, Kaled Abou. 2014. Reasoning with God: Reclaiming Shariah in the modern age. London: Rowman \& Littlefield. 
El Gamal, Mahmoud. 2007. Mutuality as an antidote to rent-seeking Shariah arbitrage in Islamic finance. Thunderbird International Business Review 49 (2): 187-202.

Elgariani, Fawzy Shaban. 2012. Al-Qawā’id al-Fiqhiyyah (Islamic Legal Maxims): Concept, Functions, History, Classifications and Application to Contemporary Medical Issues. Ph.D. Thesis, University of Exeter. https://ore.exeter.ac.uk/repository/bitstream/han dle/10036/4001/ElgarianiF.pdf? sequence $=2$ \&isAllowed $=y$.

Fadel, Mohammad. 2008. Riba, efficiency, and prudential regulation: Preliminary thoughts. Wisconsin International Law Journal 25:655-702.

Fidrus, Sukor. 2012. Takaful and Waqf: An ideal partnership. Islamic Finance News Supplements, 7 May. https://www.islamicfinancenews.com/takaful-and-waqf-an-idealpartnership.html.

Hamoudi, Haider Ala. 2007a. Jurisprudential schizophrenia: On form and function in Islamic finance. Chicago Journal of International Law 7 (2): 605-22.

- 2007b. Muhammad's social justice or Muslim cant? Langdellianism and the failures of Islamic finance. Cornell International Law Journal 89:89-133.

- 2008. The muezzin's call and the Dow Jones bell: On the necessity of realism in the study of Islamic law. The American Journal of Comparative Law 56:423-69.

Hallaq, Wael B. 1984. Was the gate of Ijtihad closed? International Journal of Middle East Studies 16 (1): 3-41.

— 1985-1986. The logic of legal reasoning in religious and non-religious cultures: The case of Islamic law and the common law. Cleveland State Law Review 34:79-96.

- 1999. A history of Islamic legal theories. Cambridge: Cambridge University Press.

Ingold, Tim. 2015. The life of lines. Abingdon: Routledge.

- 2017. On human correspondence. Journal of the Royal Anthropological Institute 23 (1): 9-27.

Jadalhaq, Iyad, and Mohammed El Hadi El Maknouzi. 2019. Reading UAE contract law through the lens of Islamic jurisprudence: A case study on the "extraneous cause" exception in the UAE Civil Code. Global Jurist 19 (2). doi: 10.1515/gj-2018-0045

Kamali, Mohammad Hashim. 2002. Issues in the understanding of Jihād and Ijtihād. Islamic Studies 41 (4): 617-34.

Kamali, Mohammad Hashim. 2006. Legal maxims and other genres of literature in Islamic jurisprudence. Arab Law Quarterly 20 (1): 77-101.

Khan, Liaquat Ali. 2009. Jurodynamics of Islamic law. Rutgers Law Review 61 (2): 231-93.

Lang, George. 1996. Jihad, Ijtihad, and other dialogical wars in La Mère du printemps, Le Harem politique, and Loin de Médine. In The marabout and the muse: New approaches to Islam in African literature, ed. Kenneth W. Harro, 1-22. Portsmouth, NH: Heinemann.

MacIntyre, Alasdair. 2007. After virtue: A study in moral theory. Notre Dame, IN: Notre Dame University Press.

- 2006. Islamic law: God's law or men's law? In Comparative Law in a Global Context, ed. Werner Menski, 279-379. Cambridge: Cambridge University Press.

Murphy, Brendon, and Jeffrey McGee. 2015. Phronetic legal inquiry: An effective design for law and society research? Griffith Law Review 24 (2): 288-313.

Nana, Abdullah. 2016. A proposed marriage between endowments, mutual insurance and the institution of agency in Islamic law: An introduction to the waqf-wakalah model of takäful. In Takaful and Islamic Cooperative Insurance: Challenges and Opportunities, ed. S. Nazim Ali and Shariq Nisar, 62-92. Cheltenham: Edward Elgar.

Reinhart, A. Kevin. 1983. Islamic law as Islamic ethics. The Journal of Religious Ethics 11 (2): 186-203. 
Rosen, Lawrence. 1989. The anthropology of justice: Law as culture in Islamic society. Cambridge: Cambridge University Press.

Sacco, R. 1991. Legal formants: A dynamic approach to comparative law (instalment I of II). American Journal of Comparative Law 39:1-34

Slater Gittes, Katharine. 1983. The Canterbury Tales and the Arabic frame tradition. Modern Language Association 98 (2): 237-51.

Shatzki, Theodore R. 2012. A primer on practices: Theory and research. In Practice-based education: Perspectives and strategies, ed. J. Higgs, R. Barnett, S. Billett, M. Hutchings, and F. Trede, 13-26. Rotterdam: Sense Publishers.

Shehaby, Nabil. 1982. 'Illa and Qiyās in early Islamic legal theory. Journal of the American Oriental Society 102 (1): 27-46.

Tomeh, Mamoud Munes. 2010. Persuasion and authority in Islamic law. Berkeley Journal of Middle Eastern and Islamic Law 3:141-71.

Weiss, Bernard G. 2006. The spirit of Islamic law. Athens, GA: University of Georgia Press

Young, Walter Edward. 2017. The dialectical forge: Juridical Disputation and the evolution of Islamic law. Cham, Switzerland: Springer International.

\section{Legislation cited}

Federal Law on Civil Transactions 1985 (UAE Civil Code). Official Gazette 158 (part 12): 11. Federal Waqf Law No. 5 of 2018 (UAE Waqf Law). Official Gazette 630:17-38.

Resolution No. 4 of 2010 of the Insurance Authority, Concerning the Takaful Insurance Regulations (UAE Takaful Insurance Regulations). Official Gazette 40 (510): 205-224.

Iyad Mohammad Jadalhaq

Professor of Civil Law

Department of Legal Studies, Zayed University

Iyad.jadalhaq@zu.ac.ae

Luigi Russi

Research-in-Action Community, Schumacher Society

luigi.russi@plymouth.ac.uk 